\title{
"We Need a Song of Hope": Responding to the COVID-19 Informational and Psychospiritual Needs of Residents of a Gated Community in the Philippines
}

\author{
Godwin Nwadibia Aja ${ }^{1}$ (D) . Jose Francisco ${ }^{1}$. Muriel Matunga ${ }^{1} \cdot$ Adma Trye $^{1}$. \\ Baiada Lyngdoh ${ }^{1}$. Cynthia Zambelli ${ }^{1}$ - Victoria Tayo Aja ${ }^{2}$
}

Accepted: 13 March 2021 / Published online: 29 March 2021

(c) The Author(s), under exclusive licence to Springer Science+Business Media, LLC, part of Springer Nature 2021

\begin{abstract}
The brutal disruptions caused by the novel coronavirus (COVID-19) pandemic require dynamic ways of responding, not only to the informational needs of communities, but also engaging and creating interventions they consider relevant to their psychospiritual needs. Using the design thinking steps, we identified, developed and tested the type and nature of a unique song which residents of a gated community needed in their journey through COVID-19 lockdowns and government restrictions. The design thinking model provided clear steps for engaging residents to develop an anti-COVID-19 song of hope to cope with the physical, sociopolitical, psychological and spiritual trauma caused by the pandemic.
\end{abstract}

Keywords Songs · COVID-19 · Coronavirus prevention and control · Psychospiritual $\cdot$ Design thinking

\section{Introduction}

The COVID-19 pandemic has left an unprecedented mark in the lives and well-being of individuals, families, communities and organizations. Till date, scientists are still battling hard to find pharmaceutical solutions to the problem. Meanwhile, countries are doing their best to implement non-pharmaceutical interventions (NPIs), such as prohibition of public gatherings, compulsory stay-at-home legislation, compulsory school closures, face mask rules and quarantine (Hartley \& Perencevich, 2020). The

Godwin Nwadibia Aja

gndaja@gmail.com

1 Graduate School Public Health Department, Adventist International Institute of Advanced Studies, Silang, Cavite, Philippines

2 Applied Theology Department, Theological Seminary, Adventist International Institute of Advanced Studies, Silang, Cavite, Philippines 
intention of these measures is to protect and promote public health and well-being (WHO, 2020). However, these measures have led to anxiety, depression and distress (Bäuerle et al., 2020), coronaphobia (Asmundson \& Taylor, 2020) and emotional impact (Brooks et al., 2020; Lima, Lopes \& Brito, 2020; Lima, Carvalho, et al., 2020). Major culprits include frontline healthcare workers, individuals infected with and affected by COVID-19, individuals impacted by the prolonged restrictions, and individuals with existing mental health issues (Inchausti et al., 2020). Psychological support (Bäuerle et al., 2020) via hotline (Geoffroy et al., 2020), including spiritual care (del Castillo et al., 2020), has been used to mitigate the effects of the NPIs.

However, unusual situations require innovative designs within the context of the problem to achieve sustainability (Cankurtaran \& Beverland, 2020; Valentine et al., 2017). The application of design thinking process is useful in searching and exploring complex health problems (Lewis et al., 2020), health systems issues (McLaughlin et al., 2019) and implementing public health solutions (Ramaswamy et al., 2019). Design thinking is useful, feasible and applicable to multiple health care domains such as diabetes, posttraumatic stress disorder, chronic obstructive pulmonary diseases and others (Altman et al., 2018). It can be used to create, implement and refine the health professions curricula and educational programs (McLaughlin et al., 2019) and address limitations of digital mental health interventions for youth (Scholten \& Granic, 2019), men, women and children.

WHO (2020) supports context-specific social interventions that are acceptable and sustainable. Songs, a social intervention, have been used as a tool to transmit vital health messages (Aja et al., 2011). Currently, information on COVID-19 prevention and control is mostly transmitted in electronic forms and other media of communication, although in the wake of the COVID-19 pandemic, songs have been used to promote personal and collective responsibility on prevention and control (UNESCO, 2020). A song was presented by the Chinese Embassy in the Philippines as a tribute to frontline health workers (CNN, 2020), for those infected with COVID19 (CGTN, 2020) and for friends and families (The Star, 2020). Other efforts include a musical concert by the World Health Organization (WHO), in partnership with Global Citizen to celebrate frontline health care workers; songs by musicians in Africa on COVID-19 protective measures; the Stay at Home Festival on Instagram live by The Orchard music company in the USA; and the Quarantine Fest in Spain (Global Citizen, 2020).

Songs alone or in combination with other interventions such as drama, dance and music have been used to increase early breastfeeding initiation and exclusive breastfeeding (Flax et al., 2014), send preventive messages about HIV/AIDS (Wenje et al., 2011), address development and health related issues such as chronic poverty, famine, disease outbreaks and family planning (Fayoyin \& Nieuwoudt, 2017), treat dementia (Ekra \& Dale, 2020), bring positive behavioral and social change (Calo et al., 2020), educate and improve knowledge about diseases (Yoshida et al., 2012) and improve healthy habits in women (Singh et al., 2017). Thus, use of songs could be one of the ways of reaching more people with COVID-19 preventive messages, particularly religious communities. Religious communities are known to use songs to manage stress (Hamilton et al., 2013). In this context, this study sought to 
identify, develop and test the type and nature of a song residents of a gated community needed in their journey through COVID-19 lockdowns and government restrictions. In the Philippines, religion is crucial to the well-being of the people (World Population Review, 2020) and tends to give meaning to life (Rovers \& Kocum, 2010) in general. The lockdown policies and restrictions on religious gatherings impact on the spiritual lives of the population, thus requiring innovative approaches to deliver religious and spiritual services and care to members (Catholic Bishops Conference of the Philippines, 2020; del Castillo et al., 2020).

\section{Methodology}

This study used a cross-sectional study design, following the five stages of design thinking as a theoretical framework (Dam \& Siang, 2021). These stages comprise: (1) empathize — research your users' needs, (2) define—-state your users' needs and problems, (3) ideate—challenge assumptions and create ideas, (4) prototype-start to create solutions, (5) test-try your solutions out (Fig. 1).

In stages 1 and 2, we invited 150 residents of a gated community to participate in an online survey to define the type and nature of a song that kept them going amidst COVID-19 pandemics. The validated semi-structured online Google survey form/ questionnaire, developed in English Language, and sent through the group's email addresses, sought information from residents, 18 years and above, who volunteered to participate in the study. Of the 150 participants invited to participate in the study, 46 residents completed the survey questionnaire: a response rate of $31 \%$. The survey questionnaire in stages 1 and 2 comprised of four parts. Part A elicited information on the demographic profile of the residents. Part B sought open-ended data on sources of information on COVID-19. Part C focused on choice of COVID 19 songs residents listened to, and Part D assessed their willingness to participate in developing a COVID-19 song. We used descriptive statistics to analyze the data.

On the basis of the findings from stages 1 and 2, we created ideas (ideate-stage 3 ) around the type and nature of a song on COVID-19 preventive and psychospiritual messages the residents needed, such as Christian, secular or traditional songs. The processes involved in the development of the song included an initial draft of the lyrics and music by one of the investigators, review of the lyrics and music by three investigators and further reflections and revisions by the investigators/authors. All the processes were done via Zoom virtual meetings. The investigators created a song (prototype — stage 4) highlighting COVID-19 preventive and psychospiritual

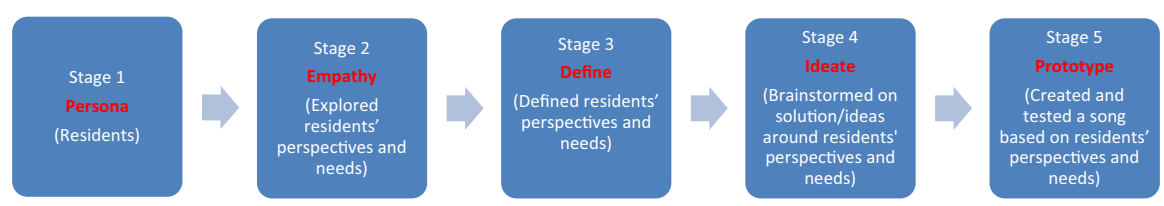

Fig. 1 Application of the design thinking stages for responding to the COVID-19 informational and psychospiritual needs of residents of a gated community in the Philippines (based on Dam \& Siang, 2021) 
messages to address the informational and psychological needs of the residents. The investigators tested the song among residents who participated in stages 1 and 2 to determine the relevance of the song to their felt need (test-stage 5). The online Google form used to test the song elicited information on the demographic profile of the residents, confirmation of having listened to the song and their feedback concerning the song.

To ensure compliance with ethical standards of research, the investigators sought the permission of AIIAS Ethical Review Board (MIN: 2020-31) before embarking on this study. Participation in this study was voluntary. Participants were free to withdraw their consent and to discontinue participation at any time without penalty.

\section{Results}

The results of this study are in three parts. Part 1 presents the sociodemographic characteristics of the residents, including informational and psychospiritual needs assessment results. Part 2 presents the lyrics of the COVID-19 song, including informational and psychospiritual highlights of the song (stage 4). Part 3 presents the results of the validation of the song that emerged from stages 1 to 5 of the design thinking process.

Part 1 Of the residents invited to participate in the study, 46 (31\%) completed the online survey. Twenty-nine (63\%) were males, 26 (46\%) were married, 14 (30\%) were aged 40-45, twenty-five (54\%) were from Africa, 24 (52\%) with a Master's degree, 36 (78\%) were students and 45 (98\%) were Christians (Table 1).

Responses from the open-ended questions showed that the major sources of information on COVID-19 and categories of songs that kept residents going during the COVID-19 lockdown were from the social media and television, and Christian and secular songs, respectively. About $31(67.4 \%)$ said they have heard of a song conveying COVID-19 prevention and control messages (Table 2a). On what residents learnt from the songs on COVID-19, they listed safety measures for COVID-19 prevention.

On whether they would like to listen to a "new" song that conveys COVID-19 prevention and control messages and hope, 37 (80.4\%) said yes (Table 2b). Majority of the participants said they would like a song of hope $24(52.1 \%)$ and awareness 13 (28.3\%) (Table 2c). Majority, 36 (78.3\%) would like a Christian song (Table 2d).

Majority of the participants were willing to participate in developing a song that promotes COVID-19 prevention and control and hope, 28 (60.9\%) (Table 2e). Six (13\%) indicated interest to play guitar (Table 2f). On the preferred language of COVID-19 prevention and control songs, majority of the participants, 21 (45.7\%) (Table 2g), indicated English Language and expressed willingness to participate in the music video, 23 (50\%) (Table 2h).

Part 2 Based on the data presented above, we developed a song. Table 3 shows the lyrics of the five stanzas and the chorus of the song highlighting COVID-19 prevention and control, specifically on protective measures, personal responsibility (the role of each person in preventing the disease and saving lives), collective actions we 
Table 1 Sociodemographic characteristics

\begin{tabular}{|c|c|c|}
\hline Sociodemographic characteristics & Number & $\begin{array}{l}N=46 \\
\%\end{array}$ \\
\hline \multicolumn{3}{|l|}{ a. Gender } \\
\hline Male & 29 & 63 \\
\hline Female & 17 & 37 \\
\hline \multicolumn{3}{|l|}{ b. Social status } \\
\hline Married & 26 & 46 \\
\hline Single & 20 & 44 \\
\hline \multicolumn{3}{|l|}{ c. Age in years } \\
\hline $40-49$ & 14 & 30 \\
\hline $25-29$ & 12 & 26 \\
\hline $30-39$ & 10 & 22 \\
\hline 50 and above & 7 & 15 \\
\hline $18-24$ & 4 & 9 \\
\hline \multicolumn{3}{|l|}{ d. Continent of origin } \\
\hline Africa & 25 & 54 \\
\hline Asia & 14 & 31 \\
\hline Americas & 7 & 15 \\
\hline \multicolumn{3}{|l|}{ e. Highest educational attainment } \\
\hline Master & 24 & 52 \\
\hline College & 12 & 26 \\
\hline Doctorate & 10 & 22 \\
\hline \multicolumn{3}{|l|}{ f. Educational status } \\
\hline Student & 36 & 78 \\
\hline Faculty & 5 & 11 \\
\hline Staff & 4 & 9 \\
\hline Other & 1 & 2 \\
\hline \multicolumn{3}{|l|}{ g. Religion } \\
\hline Christianity & 45 & 98 \\
\hline Others & 1 & 2 \\
\hline
\end{tabular}

need to take to protect others, including spiritual connections and action that foster hope amidst the trauma caused by the COVID-19 pandemic.

Part 3 The results of the validation of the song among the residents show that of the 46 residents who participated in Part 1 of the study, 12 validated the song (response rate of $26 \%)$. Nine (75\%) were males, $6(50 \%)$ were married, $3(25 \%)$ were across all the age groups, 7 (58.3\%) were from Africa, 7 (58.3\%) with a Master's degree, $10(83.3 \%)$ were students and $12(100 \%)$ were Christians (Table 4).

Of the 12 who listened to the song, $11(91.7 \%)$ liked it. Majority of the residents identified awareness, $11(91.7 \%)$ and hope, $8(66.7 \%)$ as the key messages of the song. One of the residents would like a "more vibrant tune" to be added to the song and for the song to be "shorter and less wordy." Seven $(58.3 \%)$ classified the song as Christian, and $9(75 \%)$ indicated that the song should be translated to 
Table 2 Type and nature of a song

\begin{tabular}{|c|c|c|}
\hline Statement & Number & $\%$ \\
\hline \multicolumn{3}{|c|}{ a. Heard of any song used to convey COVID-19 message } \\
\hline Yes & 31 & 67.4 \\
\hline No & 15 & 33.6 \\
\hline \multicolumn{3}{|c|}{ b. Would like to listen to a song that conveys COVID-19 prevention and control messages } \\
\hline Yes & 37 & 80.4 \\
\hline No & 9 & 19.6 \\
\hline \multicolumn{3}{|c|}{ c. Nature of song to hear } \\
\hline Hope & 24 & 52.1 \\
\hline Awareness & 13 & 28.3 \\
\hline Resilience & 4 & 8.7 \\
\hline Attitudinal change & 1 & 2.2 \\
\hline \multicolumn{3}{|c|}{ d. Type of song to hear } \\
\hline Christian & 36 & 78.3 \\
\hline Secular & 3 & 6.5 \\
\hline Traditional & 6 & 13 \\
\hline Other & 1 & 2.2 \\
\hline \multicolumn{3}{|c|}{ e. Willingness to participate in a song } \\
\hline Yes & 28 & 60.9 \\
\hline No & 18 & 39.1 \\
\hline \multicolumn{3}{|c|}{ f. Willingness to play musical instrument } \\
\hline Piano & 4 & 8.7 \\
\hline Guitar & 6 & 13 \\
\hline Violin & 1 & 2.2 \\
\hline None & 35 & 76.1 \\
\hline \multicolumn{3}{|c|}{ g. Willingness to sing in my own language } \\
\hline English & 21 & 45.7 \\
\hline Spanish & 4 & 8.7 \\
\hline Filipino & 0 & 0 \\
\hline Other & 21 & 45.6 \\
\hline \multicolumn{3}{|c|}{ h. Willingness to be a part of the music video } \\
\hline Yes & 23 & 50 \\
\hline No & 23 & 50 \\
\hline
\end{tabular}

local languages: Filipino-2 (16.6\%), French-2 (16.6\%), Swahili-1 (8.3\%), Amharic-1 (8.3\%), Igbo-1 (8.3\%), Khasi-1 (8.3\%), and Mongolian-1 (8.3\%) (Table 5). 
Table 3 Lyrics of the song on COVID-19 prevention and control

COVID-19 lyrics

Informational and psychospiritual

highlights of the song

Every one of us should play a part to prevent the COVID-19

Collective action against COVID-19

Any choice you make affects everyone

Our choices have a multiplier effect

Be aware of what you do

Awareness is important

Avoid to touch your nose, mouth and your face

Personal preventive action

Keep a little distance from the crowd and friends

Physical/social distancing is essential

This is how we can prevent and save someone from Corona virus

Stay home

Wash hands with water and soap

Stay at home for quarantine

Use sanitizer

Let's prevent this COVID-19

Wash your hands with water and soap

Or use the sanitizer

When we trust in the Lord, we obey regulations for our well-being

Spiritual action

Do not take any rule for granted

Trust in God

Helping each other we can win

Obedience

Victory together

Avoid to touch your nose, mouth and your face-

Personal preventive action

Keep a little distance from the crowd and friends-This is how we can prevent and save someone from Corona virus-

Maintain respiratory hygiene

Physical/social distancing is essential

We believe in the promises of God

Soon and very soon all these things shall pass

Spiritual action

He cares for us, watches us, no need to doubt

Believe in God and His promises

Hope in God's care and time

In His time, we'll understand

\section{Discussion}

Residents relied on social media and television as the major sources of information on COVID-19. Social media platforms are common sources of COVID-19 information (Ali \& Bhatti, 2020), particularly via tweets (Gough et al., 2017). It is rapid (Chan et al., 2020), with obvious drawbacks (Lima, Lopes \& Brito, 2020; Lima, Carvalho, et al., 2020), and requires filtering (Pariser, 2012).

The design thinking model provided a clear framework that can lead to innovative solution development (Cankurtaran \& Beverland, 2020). In our study, we identified, developed and tested the type and nature of a song residents of a gated community needed in their journey through COVID-19 lockdowns and government restrictions. The profile of the participants suggests a diverse community of Christian residents, mostly students from Africa. International students are more 
Table 4 Sociodemographic characteristics of residents at pilot test of the song

\begin{tabular}{|c|c|c|}
\hline Sociodemographic characteristics & Number & $\begin{array}{l}N=12 \\
\%\end{array}$ \\
\hline \multicolumn{3}{|l|}{ Gender } \\
\hline Male & 6 & 50 \\
\hline Female & 6 & 50 \\
\hline \multicolumn{3}{|l|}{ Social status } \\
\hline Married & 9 & 75 \\
\hline Single & 3 & 25 \\
\hline \multicolumn{3}{|l|}{ Age } \\
\hline $40-49$ & 3 & 25 \\
\hline $25-29$ & 3 & 25 \\
\hline $30-39$ & 3 & 25 \\
\hline 50 and above & 3 & 25 \\
\hline $18-24$ & 0 & 0 \\
\hline \multicolumn{3}{|l|}{ Continent of origin } \\
\hline Africa & 7 & 58.3 \\
\hline Asia & 4 & 33.3 \\
\hline Americas & 1 & 8.3 \\
\hline \multicolumn{3}{|l|}{ Highest educational attainment } \\
\hline Master & 7 & 58 \\
\hline College & 2 & 17 \\
\hline Doctorate & 3 & 25 \\
\hline \multicolumn{3}{|l|}{ Educational status } \\
\hline Student & 10 & 83.3 \\
\hline Faculty & 1 & 8.3 \\
\hline Staff & 1 & 8.3 \\
\hline \multicolumn{3}{|l|}{ Religion } \\
\hline Christianity & 12 & 100 \\
\hline
\end{tabular}

likely to feel isolated (Wa-Mbaleka \& Joseph-Collins, 2013) especially in the wake of COVID-19 pandemic and may need something more than information to cope with the pandemic.

In our study, the respondents tended to draw inspirations from Christian songs. Christian songs that address cognitive and emotive states (Tonsing et al., 2015) may be attractive to Christians in times of crises. Some kinds of music may improve blood pressure (Sutoo \& Akiyama, 2004), enhance positive emotional states (McCraty et al., 1996) and can be used to educate and improve knowledge about diseases (Yoshida et al., 2012) and facilitate relaxation (Krout, 2007).

Right from the onset of the pandemic, there were varieties of music on COVID19 (CNN, 2020; CGTN, 2020; The Star, 2020; Global Citizen, 2020). In our study, the residents indicated that they have heard of songs conveying COVID-19 prevention and control messages. Despite having heard of the songs, residents still indicated that they would you like to listen to a "new" song that conveys COVID-19 
Table 5 Residents' assessment of the song

\begin{tabular}{lll}
\hline Statement & Number & $\%$ \\
\hline Listened the song & & \\
Yes & 12 & 100 \\
No & 0 & 0 \\
Liked the song & & \\
Yes & 11 & 91.7 \\
No & 1 & 8.3
\end{tabular}

Key messages of the song ${ }^{\mathrm{a}}$

Awareness 11

Hope 8

Resilience

Attitudinal change

What to add to the song

More vibrant tune

Nothing

What to remove from the song

Short length and less wordy

Nothing

Song classification

Christian

Traditional

Secular

Others

Like the song to be translated

Yes

No

Like song to be translated to

\begin{tabular}{lll} 
Amharic & 1 & 8.3 \\
English & 1 & 8.3 \\
Filipino & 2 & 16.7 \\
French & 2 & 16.7 \\
Igbo & 1 & 8.3 \\
Khasi & 1 & 8.3 \\
Mongolian & 1 & 8.3 \\
Swahili & 2 & 16.7 \\
None & 1 & 8.3 \\
\hline
\end{tabular}

${ }^{\mathrm{a}}$ Multiple responses

prevention and control message and hope. Perhaps, they wanted a song that not only provides information about COVID-19 but a song that connects them to God. The majority of the participants would not only want to hear a Christian song (a song of hope); they were willing to participate in developing a song that promotes COVID19 prevention and control as well as hope. Songs have been shown to bring positive 
and behavioral changes (Caló et al., 2020), as well as educate and improve knowledge of diseases (Yoshida et al., 2012). The COVID-19 song from our study communicates risk with specific information on COVID-19 protective measures, personal responsibility, collective action and spiritual connection with God.

\section{Limitations of the Study}

This study is limited to one community. For this reason, the result may not be applicable or generalized to bigger population. Nevertheless, the result of the study could benefit other gated religious communities by serving as a platform for similar study in other areas of need.

\section{Conclusion}

The COVID-19 pandemic has left unprecedented mark in the lives and wellbeing of diverse cultures, including Christian communities. With the innovative action steps which the design thinking model provides, our study explored and responded to the COVID-19 informational and psychospiritual needs of residents of a gated community in the Philippines by developing and testing a song. The findings of our research corroborate the positive impact of songs of hope on stress. In response to the participants' desire for a song of hope, this study concludes that the design thinking model provided clear steps for engaging residents to develop an anti-COVID-19 song of hope to cope with the physical, sociopolitical, psychological, and spiritual trauma caused by the pandemic. We recommend that future research should utilize the design thinking model to assess residents' informational and psychospiritual perspectives and needs in other crisis issues beyond COVID-19, as well as evaluate the impact of the COVID-19 song on the prevention behavior of residents.

\section{References}

Aja, G. N., Umahi, E. N., \& Allen-Alebiosu, O. I. (2011). Developing culturally-oriented strategies for communicating women's health issues: A church-based intervention. Education for Health, 24(1), 1-10.

Ali, M. Y., \& Bhatti, R. (2020). COVID-19 (Coronavirus) pandemic: Information sources channels for the public health awareness. Asia Pacific Journal of Public Health, 32(4), 168-169. https://doi. org/10.1177/1010539520927261.

Altman, M., Huang, T., \& Breland, J. (2018). Design thinking in health care. Preventing Chronic Disease, 15(9), 180128. https://doi.org/10.5888/pcd15.180128.

Asmundson, G., \& Taylor, S. (2020). Coronaphobia: Fear and the 2019-nCoV outbreak. Journal of Anxiety Disorders, 70, 102196. https://doi.org/10.1016/j.janxdis.2020.102196.

Bäuerle, A., Skoda, E. M., Dörrie, N., Bottcher, J., \& Teufel, M. (2020). Psychological support in times of COVID-19: The Essen community-based CoPE concept. Oxford Academic Journal of Public Health, 42(3), 649-650. https://doi.org/10.1093/pubmed/fdaa053. 
Brooks, S. K., Webster, R. K., Smith, L. E., Woodland, L., Wessely, S., Greenberg, N., \& Rubin, G. J. (2020). The psychological impact of quarantine and how to reduce it: Rapid review of the evidence. Lancet, 395, 912-920. https://doi.org/10.1016/S0140-6736(20)30460-8.

Caló, F., Steiner, A., Millar, S., \& Teasdale, S. (2020). The impact of a community-based music intervention on the health and well-being of young people: A realist evaluation. Health and Social Care in the Community, 28(3), 988-997. https://doi.org/10.1111/hsc.12931.

Cankurtaran, P., \& Beverland, M. B. (2020). Using design thinking to respond to crises: B2B lessons from the 2020 COVID-19 pandemic. Industrial Marketing Management, 88, 255-260. https:// doi.org/10.1016/j.indmarman.2020.05.030.

Catholic Bishops Conference of the Philippines (2020). Liturgical Guidelines in 'New Normal' Condition. CBCP News. https://cbcpnews.net/cbcpnews/liturgical-guidelines-in-new-normal-condition/.

CGTN (2020). Italian musican composes Chinese song for COVID-19. CGTN. https://news.cgtn.com/ news/2020-03-30/Italian-musican-composes-Chinese-song-for-COVID-19-PgZTn2SB7G/index. html.

Chan, A. K. M., Nickson, C. P., Rudolph, J. W., Lee, A., \& Joynt, G. M. (2020). Social media for rapid knowledge dissemination: Early experience from the COVID-19 pandemic. Association of Anaesthestists. https://doi.org/10.1111/anae.15057.

CNN (2020). 'Iisang Dagat': Chinese Embassy dedicates song to COVID-19 frontliners in Manila, Beijing. CNN Philippines. https://www.cnnphilippines.com/news/2020/4/24/chinese-embassy-tributesong-frontliners.html.

Dam, R. F. \& Siang, T.Y. (2021). 5 Stages in the design thinking process. Denmark: Interaction design foundation. https://www.interaction-design.org/literature/article/5-stages-in-the-design-thinkingprocess.

del Castillo, F. A., Biana, H. T., \& Joaquin, J. J. B. (2020). Church in action: The role of religious interventions in times of COVID-19. Journal of Public Health. https://doi.org/10.1093/pubmed/fdaa086.

Ekra, E. M., \& Dale, B. (2020). Systematic use of song and music in dementia care: Health care providers' experiences. Journal of Multidisciplinary Healthcare, 13, 143-151. https://doi.org/10.2147/ JMDH.S231440.

Fayoyin, A., \& Nieuwoudt, S. (2017). The power of song in the struggle for health and development outcomes in Africa: Lessons for social and behaviour change programmes. Journal of Mass Communication Journalism, 7(4), 342. https://doi.org/10.4172/2165-7912.1000342.

Flax, V. L., Negerie, M., Ibrahim, A. U., Leatherman, S., Daza, E. J., \& Bentley, M. E. (2014). Integrating group counseling, cell phone messaging, and participant-generated songs and dramas into a microcredit program increases Nigerian women's adherence to international breastfeeding recommendations. Oxford Academic Journal of Nutrition, 144(7), 1120-1124. https://doi.org/10.3945/jn. 113.190124.

Geoffroy, P. A., Le Goanvic, V., Sabbagh, O., Richoux, C., Weinstein, A., Dufayet, G., \& Lejoyeux, M. (2020). Psychological support system for hospital workers during the Covid-19 outbreak: Rapid design and implementation of the Covid-Psy hotline. Frontiers in Psychiatry, 11, 511. https://doi. org/10.3389/fpsyt.2020.00511.

Global Citizen. (2020). Together at home. Global Citizen. https://www.globalcitizen.org/en/content/topics/together-at-home/.

Gough, A., Hunter, R. F., Ajao, O., Jurek, A., McKeown, G., \& Hong, J. (2017). Tweet for behavior change: Using social media for the dissemination of public health messages. JMIR Public Health and Surveillance, 3(1), 14. https://doi.org/10.2196/publichealth.6313.

Hamilton, J. B., Sandelowski, M., Moore, A. D., Agarwal, M., \& Koenig, H. G. (2013). "You need a song to bring you through": The use of religious songs to manage stressful life events. The Gerontologist, 53(1), 26-38. https://doi.org/10.1093/geront/gns064.

Hartley, D. M., \& Perencevich, E. N. (2020). Public health interventions for COVID-19: Emerging evidence and implications for an evolving public health crisis. Journal of the American Medical Association, 323(19), 1908-1909. https://doi.org/10.1001/jama.2020.5910.

Inchausti, F., MacBeth, A., Hasson-Ohayon, I., \& Dimaggio, G. (2020). Psychological Intervention and COVID-19: What we know so far and what we can do. Journal of Contemporary Psychotherapy, 27, 1-8. https://doi.org/10.1007/s10879-020-09460-w.

Krout, R. E. (2007). Music listening to facilitate relaxation and promote wellness: Integrated aspects of our neurophysiological responses to music. The Arts in Psychotherapy, 34, 134-141. https://doi.org/ 10.1016/j.aip.2006.11.001. 
Lewis, J. B., Brady, S. S., Sutcliffe, S., Smith, A. L., Mueller, E. R., Rudser, K., Markland, A. D., Stapleton, A., Gahagan, S., \& Cunningham, S. D. (2020). Converging on bladder health through design thinking: From an ecology of influence to a focused set of research questions. International Journal of Environmental Research and Public Health, 17(12), 4340. https://doi.org/10.3390/ijerph1712 4340 .

Lima, C. K. T., Carvalho, P. M. M., Lima, I. A. A. S., Nunes, J. V. A. O., Saraiva, J. S., de Souza, R. I., da Silva, C. G. L., \& Neto, M. L. R. (2020). The emotional impact of Coronavirus 2019-nCoV (new Coronavirus disease). Psychiatry Research, 287, 112915. https://doi.org/10.1016/j.psychres.2020. 112915.

Lima, D. L., Lopes, M. A. A., \& Brito, A. M. (2020). Social media: Friend or foe in the COVID-19 pandemic? Clinics, 75, 1953. https://doi.org/10.6061/clinics/2020/e1953.

McCraty, R., Atkinson, M., \& Rein, G. (1996). Music enhances the effect of positive emotional states on salivary IgA. Stress Medicine, 12, 167-175. https://doi.org/10.1002/(SICI)1099-1700(199607) 12:3\%3c167:AID-SMI697\%3e3.0.CO;2-2.

Mclaughlin, J. E., Wolcott, M. D., Hubbard, D., Umstead, K., \& Rider, T. R. (2019). A qualitative review of the design thinking framework in health professions education. BMC Medical Education. https:// doi.org/10.1186/s12909-019-1528-8.

Pariser, E. (2012). The filter bubble: How the new personalized web is changing what we read and how we think. Penguin Books.

Ramaswamy, R., Mosnier, J., Reed, K., Powell, B. J., \& Schenck, A. P. (2019). Building capacity for public health 3.0: Introducing implementation science into an MPH curriculum. Implementation Science. https://doi.org/10.1186/s13012-019-0866-6.

Rovers, M., \& Kocum, L. (2010). Development of a holistic model of spirituality. Journal of Spiritual Mental Health, 12(1), 2-24. https://doi.org/10.1080/19349630903495475.

Scholten, H., \& Granic, I. (2019). Use of the principles of design thinking to address limitations of digital mental health interventions for youth: Viewpoint. Journal of Medical Internet Research, 21(1), 11528. https://doi.org/10.2196/11528.

Singh, K., Sigroha, S., Singh, D., \& Shokeen, B. (2017). Religious and spiritual messages in folk songs: a study of women from rural India. Mental Health, Religion \& Culture, 20(5), 464-477. https://doi. org/10.1080/13674676.2017.1356812.

Sutoo, D., \& Akiyama, K. (2004). Music improves dopaminergic neurotransmission: Demonstration based on the effect of music on blood pressure regulation. Brain Research, 1016(2), 255-262. https://doi.org/10.1016/j.brainres.2004.05.018.

The Star. (2020). 5 most creative Covid-19 songs by Malaysians. The Star. https://www.thestar.com.my/ lifestyle/entertainment/2020/04/08/check-out-these-covid-19-songs-on-youtube-by-creative-malay sians.

Tonsing, J., Wepener, C., \& Vos, C. (2015). The "cognitive" and the "emotive" component in Christian songs: Tracing the shifts in traditional and contemporary songs. Verbum et Ecclesia. https://doi.org/ 10.4102/ve.v36i1.1308.

UNESCO. (2020). Health education song teaches millions about COVID-19. UNESCO. https://en.unesco.org/news/health-education-song-teaches-millions-about-covid-19.

Valentine, L., Kroll, T., Bruce, F., Lim, C., \& Mountain, R. (2017). Design thinking for social innovation in health care. The Design Journal, 20(6), 755-774. https://doi.org/10.1080/14606925.2017.13729 26.

Wa-Mbaleka, S., \& Joseph-Collins, N. (2013). International students' isolation in the Philippines: Causes, effects and coping strategies. The Development Education Journal of Multidisciplinary Research, 2, 21-54.

Wenje, P., Erick, N., \& Muhoma, C. (2011). Wende Luo' (Luo Songs) as an intervention tool in the fight against HIV/AIDS among the Luo of Western Kenya. Journal of AIDS and HIV Research, 3(8), 151-160.

World Health Organization. (2020). Overview of public health and social measures in the context of COVID-19. WHO. https://www.who.int/publications/i/item/overview-of-public-health-and-socialmeasures-in-the-context-of-covid-19.

World Population Review (2020). Philippines Population 2020 Demographics, Maps, Graphs. World Population Review. https://worldpopulationreview.com/countries/philippines-population/.

Yoshida, I., Kobayashi, T., Sapkota, S., \& Akkhavong, K. (2012). Evaluating educational media using traditional folk songs ('lam') in Laos: A health message combined with oral tradition. Oxford Academic Health Promotion International, 27(1), 52-62. https://doi.org/10.1093/heapro/dar086. 
Publisher's Note Springer Nature remains neutral with regard to jurisdictional claims in published maps and institutional affiliations. 